\title{
A new Colombian species of Liodessus diving beetles from the Páramo de Sumapaz (Coleoptera, Dytiscidae, Bidessini)
}

\author{
Michael Balke ${ }^{1,2}$, Yoandri Suarez-Megna ${ }^{3}$, Rodulfo Ospina-Torres ${ }^{4}$, \\ Juan Simon Venegas ${ }^{4}$, Carlos Prieto ${ }^{5,6}$, Lars Hendrich'
}

I SNSB-Zoologische Staatssammlung München, Münchhausenstraße 21, D-81247 Munich, Germany 2 GeoBioCenter, Ludwig Maximilians University, Munich, Germany 3 Departamento de Biología, Universidad de Oriente. Patricio Lumumba s/n, Santiago, Santiago de Cuba, Cuba 4 Departamento de Biologia, Universidad Nacional de Colombia, Bogota, Colombia 5 Departamento de Biologia, Universidad del Atlántico, Barranquilla, Colombia 6 Corporación Universitaria Autónoma del Cauca, Popayán, Colombia

Corresponding author: Michael Balke (balke.m@snsb.de)

Academic editor: Mariano Michat | Received 14 June 2021 | Accepted 27 July 2021 | Published 8 September 2021

http://zoobank.org/94DF435F-9686-4B70-A041-1921F6AOF68F

Citation: Balke M, Suarez-MegnaY, Ospina-Torres R, Venegas JS, Prieto C, Hendrich L (2021) A new Colombian species of Liodessus diving beetles from the Páramo de Sumapaz (Coleoptera, Dytiscidae, Bidessini). ZooKeys 1059: 79-87. https://doi.org/10.3897/zookeys.1059.70134

\begin{abstract}
Liodessus picinus sp. nov. is described from the Páramo de Sumapaz near Bogota D.C. at 3,500 m above sea level. The species can be distinguished from the other Colombian Liodessus species by its dark coloration, discontinuous habitus, shiny surface of the pronotum and elytron, presence of a distinct occipital line, distinct basal pronotal striae, short or even faint basal elytral striae, as well as by its distinct geographic distribution and cox 1 signature.
\end{abstract}

\section{Keywords}

Colombia, Dytiscidae, Liodessus, new species, Páramo, Sumapaz

\section{Introduction}

Diving beetles of the genus Liodessus Guignot, 1939 belong to the tribe Bidessini and occur in the New World as well as the Afrotropical Region (Biström 1988; Nilsson and Hájek 2021). They are typically smaller than $3 \mathrm{~mm}$ and inhabit a variety of mainly

Copyright Michael Balke et al. This is an open access article distributed under the terms of the Creative Commons Attribution License (CC BY 4.0), which permits unrestricted use, distribution, and reproduction in any medium, provided the original author and source are credited. 
lotic habitats. Andean species reach altitudes of nearly 5,000 m, where they are the most abundant aquatic beetles (Balke et al. 2020a, 2020b).

However, diving beetles from the high altitudes of the Puna and Páramo regions remain poorly studied. Since 2019, as the result of a research and training cooperation between our institutions, 10 new species were described from these regions of Peru (Balke et al. 2019, 2020b) and Colombia (Megna et al. 2019; Balke et al. 2021). It became apparent that many more new species of Liodessus remain to be discovered in the vast Andean highland ecosystems, most of them likely endemic to one or a few Páramo or Puna areas, respectively. To address this in a combined evidence pipeline, we suggested a DNA sequence-based platform for the study of these insects (Balke et al. 2020a, 2020b) using the Barcode of Life Data System (BOLD) of the Canadian Centre for DNA Barcoding and the 5' mitochondrial coxl gene fragment (http://www. boldsystems.org) (Ratnasingham and Hebert 2007).

It is well understood that one genetic marker alone cannot be the omnipotent tool for taxonomy, in particular markers such as cox 1 , which are not involved in speciation per se (Kwong et al. 2012). Rather, such DNA sequence data have the purpose of guiding the sorting of specimens to operational units and then flank taxonomic decision-making process. This approach has been utilized successfully to study very diverse beetle taxa (Tänzler et al. 2012; Riedel et al. 2013a, 2013b), including our own previous work on Liodessus. The approach can technically be scaled up massively using next generation sequencing technology, which is already also reducing analytical costs (Wang et al. 2018). This does, however, and that is important to note, not replace taxonomic expertise and the evaluation of morphological structures (Riedel et al. 2013a). Here, we report the discovery of another new species of Liodessus from Páramo de Sumapaz (Fig. 3A), the world's largest Páramo system, near Bogota, Colombia. Interestingly, while we sampled more than 100 specimens of Liodessus bogotensis Guignot, 1953, we only found three females of the new species.

\section{Materials and methods}

\section{Acronyms}

LIAUN Laboratorio de Insectos Acuáticos, Departamento de Biología, UniversidadNacional de Colombia, Bogota, Colombia;

ZSM SNSB-Zoologische Staatssammlung, München, Germany; temporarily stored for further morphological work.

\section{Morphological descriptions and photography}

The description of morphological characters follows our previous work on Liodessus beetles (e.g. Balke et al. 2020b). 
Images were taken with a Canon EOS R camera. We used a Mitutoyo 10x ELWD Plan Apo objective, attached to a Carl Zeiss Jena Sonnar 3.5/135 MC as focus lens. Illumination was with three LED segments SN-1 from Stonemaster (https://www.stonemaster-onlineshop.de). Image stacks were generated using the Stackmaster macro rail (Stonemaster), and images were then assembled with the computer software Helicon Focus v. 4.77TM on an iMac with a Radeon Pro 5500 XT GPU.

\section{DNA analysis}

The DNA sequencing and data analysis laboratory protocol follows standard Canadian Centre for DNA Barcoding (CCDB) barcoding procedures (https://ccdb.ca/). We delivered tissue samples to CCDB, which were processed, and the barcode data uploaded to BOLD systems. We used a simple approach to calculate a neighbour-joining tree ( $p$ distances) in Geneious software v. 11.0.4 in order to learn if newly added entries could be assigned to existing species groups or not. This approach has been proven helpful and strongly guiding the morphological descriptive process, not the least by enabling us to unambiguously identify the new species presented here in the absence of male specimens.

\section{Results}

Liodessus picinus sp. nov.

http://zoobank.org/AD2344A0-BD40-47BB-B99D-6B20430DC8A1

Figures 1, 2G, 3

Type locality. Sumapaz National Park, Bogota, Colombia.

Holotype. "Colombia, + ; Bogota D.C., PN Sumapaz; 3,500 m; 13.xi.2018;

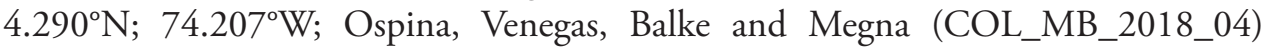
Voucher MB8416" (LIAUN).

Paratypes. 2 우우, same data but voucher numbers MB8414, 8415 (ZSM).

Description of holotype. Habitus with distinct discontinuity between pronotum and elytra (Fig. 1A), pronotum widest before base (Fig. 1A, B). Total length of beetle $2.0 \mathrm{~mm}$; length without head $1.8 \mathrm{~mm}$; maximum width $0.9 \mathrm{~mm}$.

Color. Very dark brown to blackish dorsally and ventrally, base of meso- and metatibia contrastingly of lighter color (Fig. 1A, B).

Surface sculpture. Head with few setiferous punctures in front of a distinct occipital line, distinct microreticulation present except on middle of head between the eyes (Fig. 1B); posteriorly of occipital line with distinct microreticulation and few punctures. Pronotum and elytron shiny, with moderately dense and coarse setiferous punctation; pronotum with few wrinkles laterally (Fig. 1B).

Structures. Head with distinct occipital line, with rounded clypeus. Antenna stout. Pronotum with distinct lateral bead and distinct, long and deep basal striae 

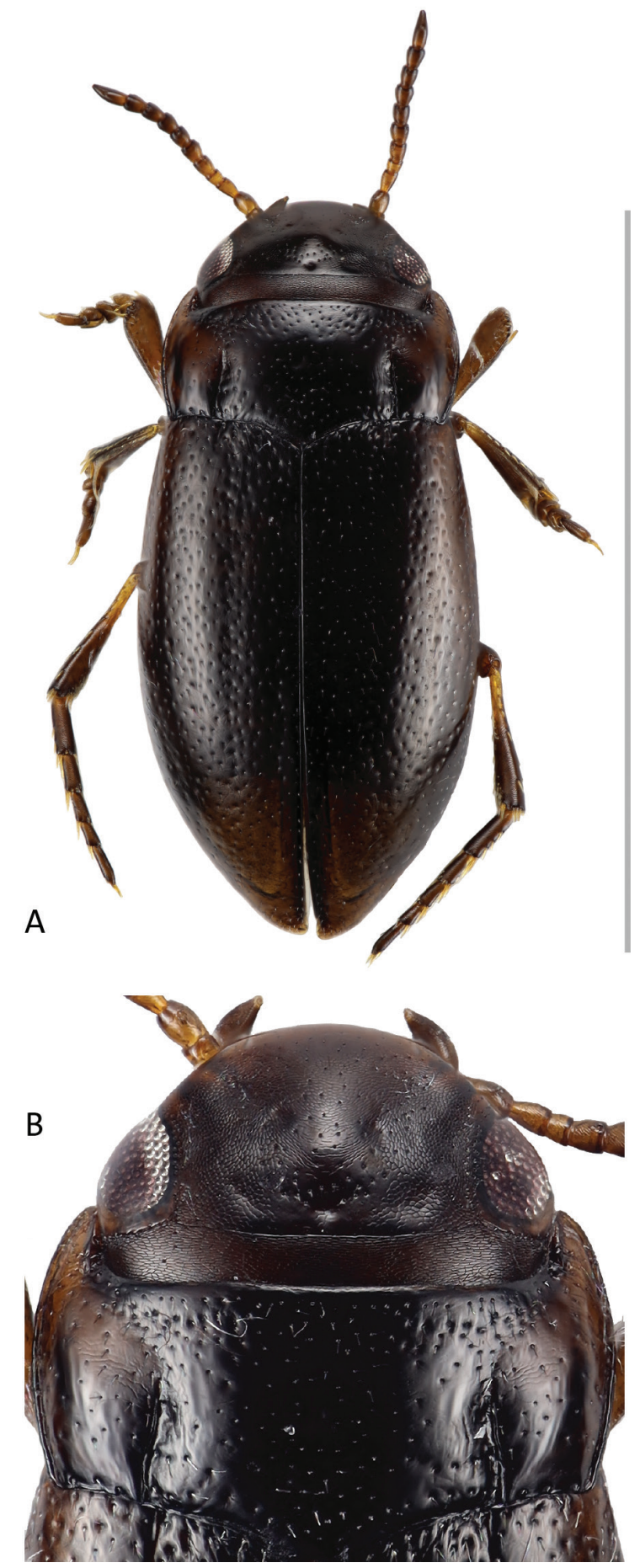

Figure I. Liodessus picinus sp. nov. A dorsal habitus B dorsal head, pronotum, and base of elytra. Scale bar: $2 \mathrm{~mm}$. 


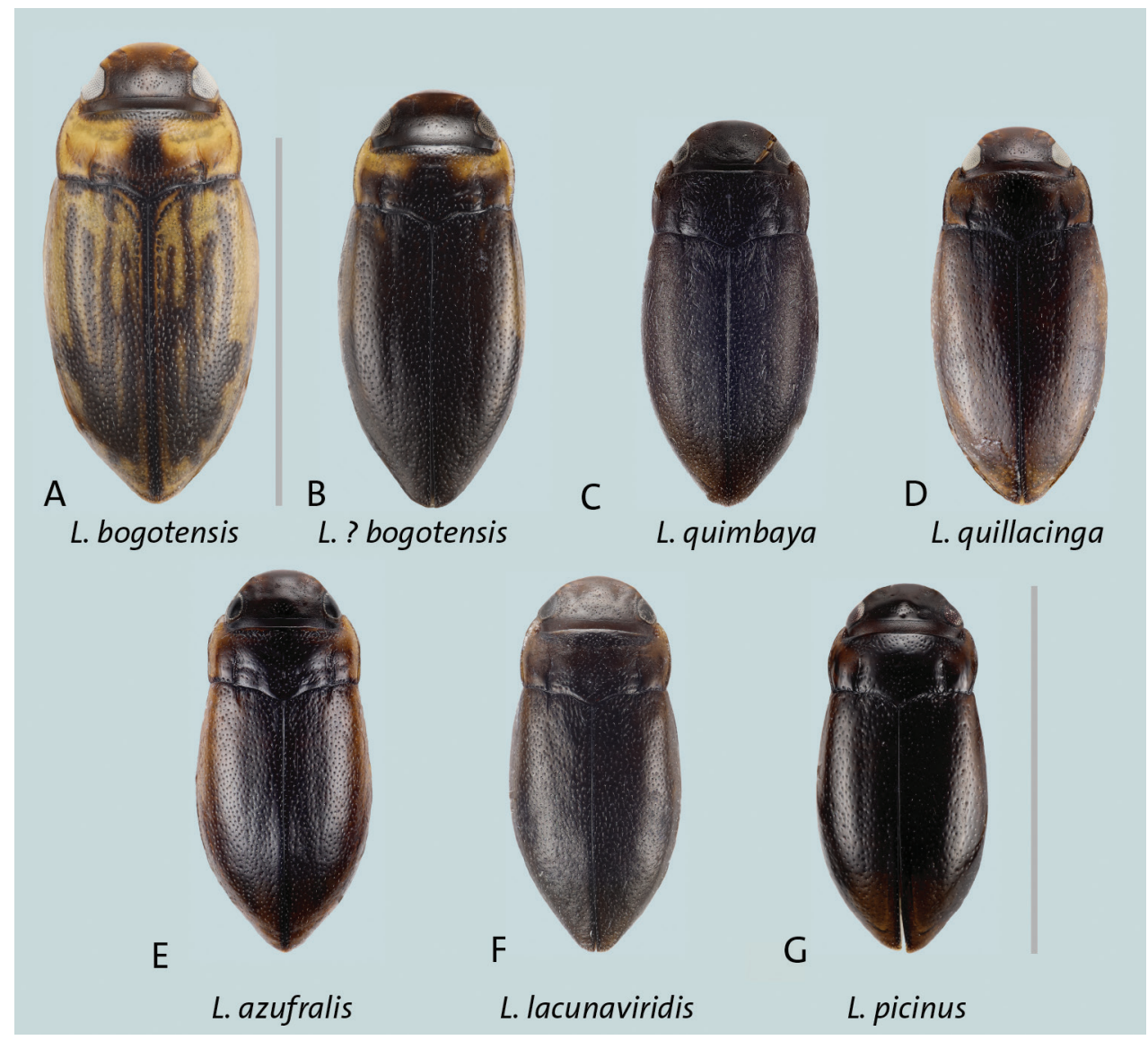

Figure 2. Liodessus spp. Dorsal habitus without appendages A L. bogotensis $\mathbf{B}$ L. bogotensis darker form from Sumapaz C L. quimbaya D L. quillacinga $\mathbf{E}$ L. azufralis $\mathbf{F}$ L. lacunaviridis $\mathbf{G}$ L. picinus sp. nov. Scale bars: $2 \mathrm{~mm}$.

(Fig. 1A, B). Elytron with short basal striae, without sutural line and without basal epipleural transverse carina. Metathoracic wings not examined in holotype (in paratype: short, about half the length of elytron).

Variation. One paratype is slightly larger, TL $2.1 \mathrm{~mm}$. In one paratype, the elytral basal striae are not very obvious.

Male. Unknown.

Etymology. Picinus, black, highlighting the dark coloration of the species.

Comparative notes. The species is well characterized by its small size (2.0-2.1 mm total length, shorter than most other Colombian Páramo species (Megna et al. 2019; Balke et al. 2021) except L. lacunaviridis (Balke et al. 2021)); dark coloration, discontinuous habitus, shiny surface of pronotum and elytrae, presence of distinct occipital line, distinct basal pronotal striae with short or even faint basal elytral striae. 


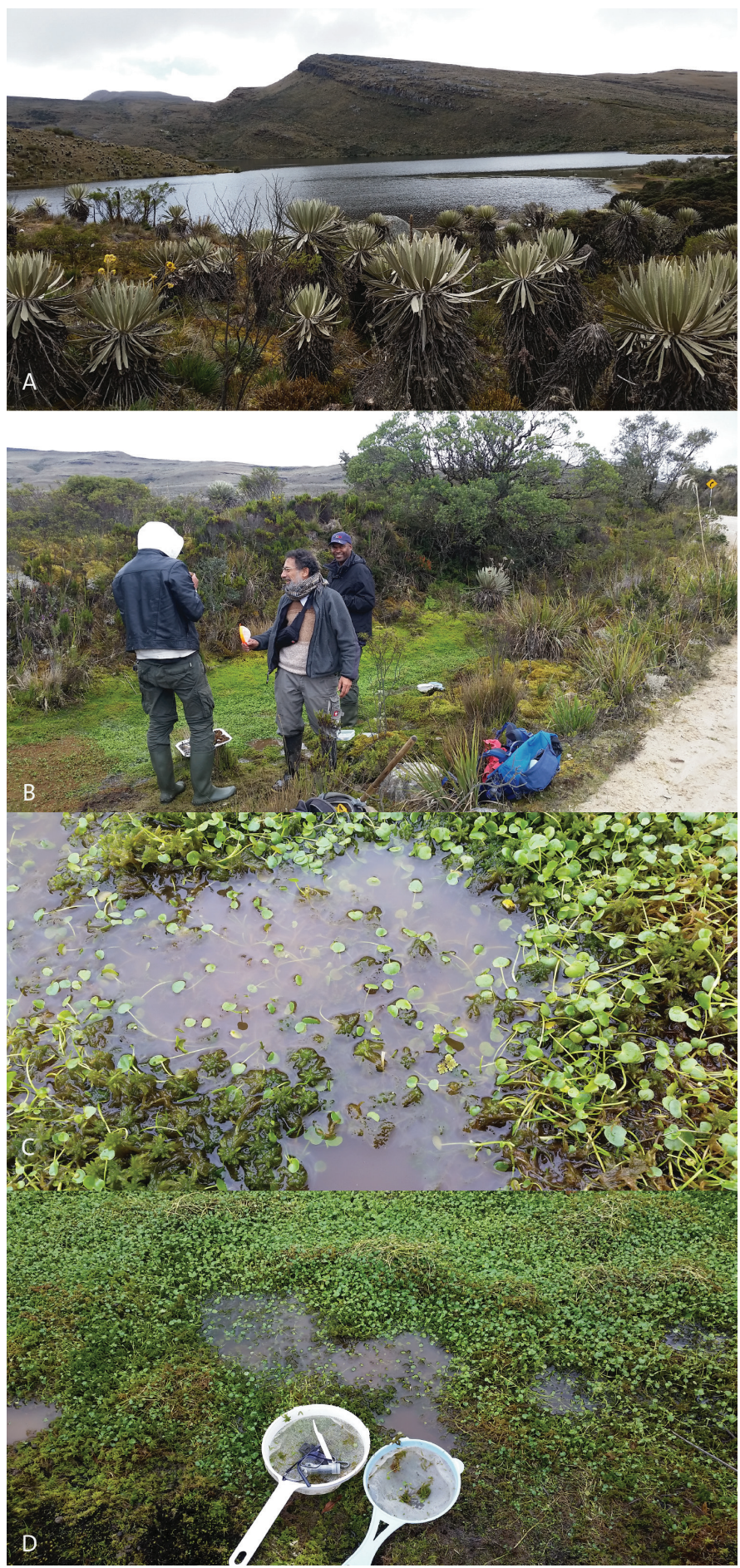

Figure 3. Habitat of Liodessus picinus sp. nov. A Sumapaz National Park, general setting B-D collecting site with collecting tools. 
We assembled sequences of the Colombian species, trimming the sequence ends to avoid missing characters. We obtained a 611 base pair reference alignment to observe sequence variation. Liodessus picinus sp. nov. differs by approx. 9-11\% (5' cox 1 ) from each of the other Colombian species and therefore forms a well-delineated clade with distinct mitochondrial coxl signature.

Distinguishing characters of the other Colombian Páramo species from the new species are:

Liodessus azufralis Megna et al., 2019: lighter coloration, brown to dark brown (Fig. 2E);

L. bogotensis: brighter coloration (Fig. 2A, B); L. lacunaviridis Balke et al., 2021 and L. quimbaya Megna et al., 2019: female with dull surface of pronotum and elytron due to presence of fine microreticulation (e.g. Fig. 2C, F); L. quillacinga Megna et al., 2019: long, distinct basal elytral stria (Fig. 2D).

Distribution. Only known from the type locality.

Habitat. Shallow and exposed peatland puddles, collected with strainer out of mats of vegetation including mosses (most likely Sphagnum sp.), Ranunculus sp. and Azolla sp. (Fig. 3B-D). The species is syntopic with L. bogotensis.

\section{Checklist of the High Andean species of Liodessus Guignot, 1953}

1. Liodessus acollensis Guignot, 1955: Peru

2. Liodessus alpinus Balke, Megna, Zenteno, Figueroa \& Hendrich, 2020b: Peru

3. Liodessus altoperuensis Balke, Megna, Zenteno, Figueroa \& Hendrich, 2020a: Peru

4. Liodessus andinus Guignot, 1957: Bolivia

5. Liodessus azufralis Megna, Hendrich \& Balke, 2019: Colombia

6. Liodessus bogotensis Guignot, 1953: Colombia

7. Liodessus caxamarca Balke, Megna, Zenteno, Figueroa \& Hendrich, 2020a: Peru

8. Liodessus hauthi Balke, Megna, Zenteno, Figueroa \& Hendrich, 2020b: Peru

9. Liodessus lacunaviridis Balke, Ospina-Torres, Megna \& Hendrich, 2020a: Colombia 10. Liodessus picinus sp. nov.: Colombia

11a. Liodessus quillacinga quillacinga Megna, Hendrich \& Balke, 2019: Colombia 11b Liodessus quillacinga cochaensis Megna, Hendrich \& Balke, 2019: Colombia 11c. Liodessus quillacinga cumbalis Megna, Hendrich \& Balke, 2019: Colombia 12. Liodessus quimbaya Megna, Hendrich \& Balke, 2019: Colombia

13. Liodessus rhigos Balke, Megna, Zenteno, Figueroa \& Hendrich, 2020b: Peru 14. Liodessus thespesios Balke, Megna, Zenteno, Figueroa \& Hendrich, 2020b: Peru

\section{Acknowledgements}

This work was made possible by a grant from the Alexander von Humboldt foundation under the Research Group Linkage Programme, Evolution of the high Andean insect fauna project. We are grateful for the generous support from the SNSB-Innovative 
scheme, funded by the Bayerisches Staatsministerium für Wissenschaft und Kunst (Project: "Geographische Isolation, Endemismus und Artbildungsprozesse bei Insekten in der hochmontanen Páramo Kolumbiens (und darüber hinaus)"). Michael Balke acknowledges support from the EU SYNTHESYS program, projects FR-TAF 6972 and GB-TAF-6776, which supported this research during visits to Natural History Museum in London and Muséum national d'Histoire naturelle in Paris in 2017. We thank the Agencia Nacional de Licencias Ambientales (ANLA) for issuing collecting and export permits. We thank Dr Simon Pflanzelt (Botanischer Garten MünchenNymphenburg) for identifying the plant genera depicted in Figure 3C and D.

Consortium of European Taxonomic Facilities (CETAF) data use statement: "Data on genetic material contained in this taxonomic article are published for non-commercial use only. Utilization by third parties for purposes other than non-commercial scientific research may infringe the conditions under which the genetic resources were originally accessed, and should not be undertaken without obtaining consent from the original provider of the genetic material."

\section{References}

Balke M, Megna YS, Zenteno N, Figueroa L, Hendrich L (2020a) New Liodessus species from the high Andes of Peru (Coleoptera: Dytiscidae, Bidessini). Zootaxa 4852: 151-165. https://doi.org/10.11646/zootaxa.4852.2.1

Balke M, Megna YS, Zenteno N, Figueroa L, Hendrich L (2020b) Two new species of Liodessus Guignot, 1939 diving beetles from Northern Peru (Coleoptera, Dytiscidae, Hydroporinae). Alpine Entomology 4: 173-178. https://doi.org/10.3897/alpento.4.55139

Balke M, Ospina-Torres R, Suarez-Megna Y, Hendrich L (2021) Liodessus lacunaviridis sp. n. from the high Andes of Colombia (Coleoptera: Dytiscidae: Hydroporinae: Bidessini). Tijdschrift voor Entomologie 163 (2020): 7-11. https://doi.org/10.1163/2211943420192084

Balke M, Suarez-Megna Y, Hendrich L, Zenteno N, Figueroa L (2019) New records for the Peruvian high-altitude diving beetle Rhantus blancasi Guignot, 1955 (Coleoptera, Dytiscidae, Colymbetinae). Check List 15: 941-944. https://doi.org/10.15560/15.5.941

Biström O (1988) Generic review of the Bidessini (Coleoptera, Dytiscidae). Contribution to the study of Dytiscidae 37. Acta Zoologica Fennica: 1-41.

Kwong S, Srivathsan A, Vaidya G, Meier R (2012) Is the COI barcoding gene involved in speciation through intergenomic conflict? Molecular Phylogenetics and Evolution 62: 1009-1012. https://doi.org/10.1016/j.ympev.2011.11.034

Megna YS, Hendrich L, García-Hernández AL, Ospina-Torres R, Prieto C, Balke M (2019) Diving beetles of the genus Liodessus Guignot, 1953 in Colombia, with description of three new species (Coleoptera: Dytiscidae). Aquatic Insects 40: 99-122. https://doi.org/10.108 0/01650424.2018.1538521 
Nilsson A, Hájek J (2021) A world catalogue of the family Dytiscidae, or the diving beetles (Coleoptera, Adephaga). Version 1. I. 2021, 315 pp. http://www.waterbeetles.eu/ documents/W_CAT_Dytiscidae_2020.pdf

Ratnasingham S, Hebert PD (2007) BOLD: the Barcode of Life Data System (http://www. barcodinglife.org). Molecular Ecology Notes 7: 355-364. https://doi.org/10.1111/j.14718286.2007.01678.x

Riedel A, Sagata K, Suhardjono YR, Tänzler R, Balke M (2013a) Integrative taxonomy on the fast track-towards more sustainability in biodiversity research. Frontiers in Zoology 10: 1-9. https://doi.org/10.1186/1742-9994-10-15

Riedel A, Sagata K, Surbakti S, Tänzler R, Balke M (2013b) One hundred and one new species of Trigonopterus weevils from New Guinea. ZooKeys: 1-150. https://doi.org/10.3897/ zookeys.280.3906

Tänzler R, Sagata K, Surbakti S, Balke M, Riedel A (2012) DNA barcoding for community ecology-how to tackle a hyperdiverse, mostly undescribed Melanesian fauna. PLoS ONE 7: 1-11. https://doi.org/10.1371/journal.pone.0028832

Wang WY, Srivathsan A, Foo M, Yamane SK, Meier R (2018) Sorting specimen-rich invertebrate samples with cost-effective NGS barcodes: Validating a reverse workflow for specimen processing. Molecular Ecology Resources 18: 490-501. https://doi.org/10.1111/17550998.12751 